\title{
Ten African American Pioneers and Mathematicians Who Inspired Me
}

\author{
by Johnny L. Houston
}

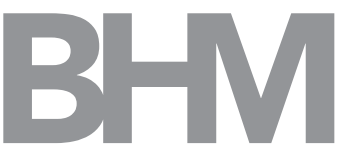

This article presents snapshots of the lives of ten African American pioneers and mathematicians who have inspired me in research, teaching, and life. The first five were amazing pioneers, and the second five were extraordinary researchers. At the end of the article are the names of five great African American mathematics teachers. In college I first learned of two of the teachers. In graduate school I learned of a few others. As my career developed, I learned of all of these persons and many more. They inspired me to be the best that I could be in the mathematical sciences community and

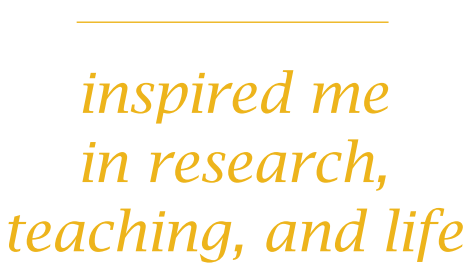
on the world scene. As a child I lived in abject poverty in governmental project housing in a one-parent family (a mother with no high school education). I was the only one of her four children to finish college. I earned three degrees in mathematics: A BA from Morehouse College, a MS from Clark Atlanta University, and a PhD from Purdue University. When I entered college I had never traveled outside the state of Georgia. By age 60, I had been to all 50 states and 60 countries on six continents and had produced over twenty publications. I want to share with young mathematicians the inspiration from earlier workers that enriched my life.

\section{BENJAMIN BANNEKER (1731-1806) Self-educated}

Benjamin Banneker was born a free Black man and was raised on a farm near Baltimore, MD. Although he period-

Johnny L. Houston is Executive Secretary Emeritus (1975-2000) of the National Association of Mathematicians. His email address is j1houston602@gmai1.com.

For permission to reprint this article, please contact: reprint-permission@ams . org.

DOI: http://dx.doi.org/10.1090/noti1639 ically attended a oneroom Quaker schoolhouse, Banneker was largely self-educated and did much of his learning through the voracious reading of borrowed books. He created puzzles for trigonometry that demonstrated his knowledge of logarithms. Banneker also attempted to find the exact lengths of an equilateral triangle inscribed within a circle where the diameter of the circle is known. While still a young man, he built a wooden clock that kept precise time until his death. As

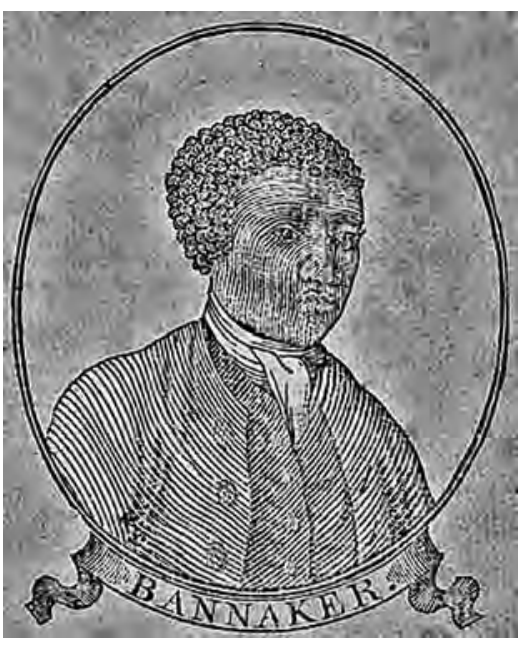

Benjamin Banneker: astronomer, mathematician, inventor, surveyor, publisher of almanacs, and author; one of the first recognized multi-talented African American intellectuals in the United States, often considered the first African American mathematician. early as 1788 , Banneker began to make astronomical calculations, and he accurately predicted a solar eclipse that occurred in 1789 . In 1791, Banneker helped survey the land that would become Washington, DC. Although a fire at his house on the day of Banneker's funeral destroyed many of his papers and belongings, one of his journals and several of his artifacts were saved and are presently available for public viewing. Many parks, schools, streets, and other entities have been named in his honor after his death. In recent years, a US postage stamp was printed in his honor. Currently the Benjamin Banneker Association, of which I was a member, promotes mathematical development at the high school level. 


\section{EDWARD}

ALEXANDER

BOUCHET (1852-

1918) Yale U. BS

1874, PhD 1876

Edward Alexander Bouchet was an American physicist and educator. He received a $\mathrm{PhD}$ from Yale in 1876 , the first by an African American from any American university. Bouchet was unable to find a university teaching position after receiving his $\mathrm{PhD}$ because of his race. He moved to Philadelphia in 1876 and took a position at Philadelphia's Institute for Colored Youth (now Cheyney

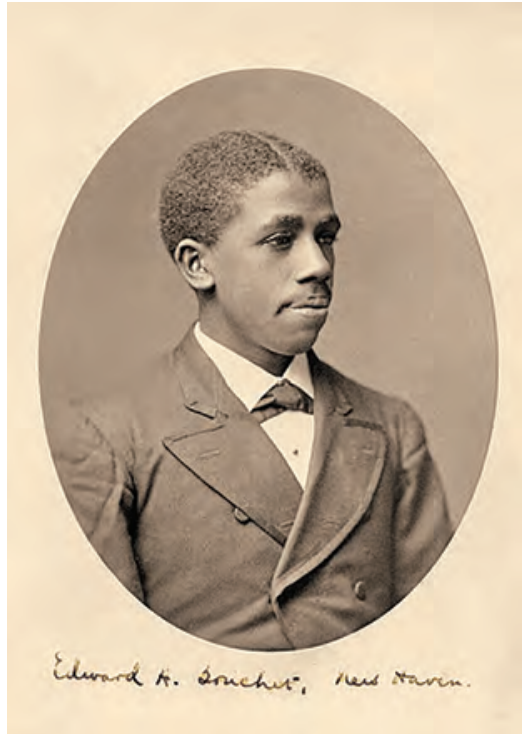

Edward Alexander Bouchet: The first African American to earn a PhD degree from an American university.
University of Pennsylvania), where he taught science and mathematics for the next twenty-six years. He resigned in 1902, spending the next fourteen years in a variety of jobs. In 1916, illness forced him to move back to his childhood home (New Haven, Connecticut), where he died in 1918. Currently, the American Physical Society confers the Edward A. Bouchet Award on some of the nation's outstanding physicists. Yale University and Howard University founded the Edward A. Bouchet Graduate Honor Society in his name. Yale also gives a Bouchet Leadership Award to help advance diversity in higher education. In 1988 the Edward Bouchet Abdus Salam Institute (EBASI) was created by Abdus Salam, a Nobel Laureate, in Trieste, Italy. One objective of EBASI is to provide for synergistic scientific and technical collaborations between African and American physical scientists. I presented at two EBASI conferences in Africa.

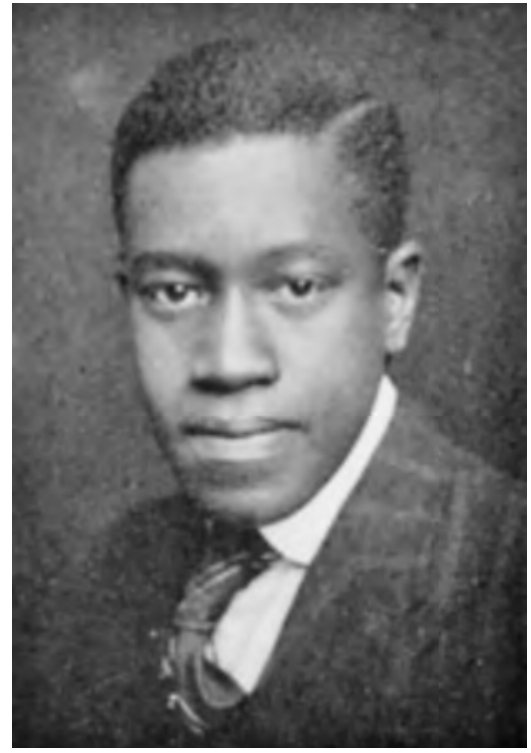

Elbert Frank Cox: The first Black person to receive a $\mathrm{PhD}$ in mathematics. Germany refused to accept Cox's dissertation (probably because of race), but Japan's Imperial University of San Dei accepted it. Cox inspired many future Black mathematicians and served a 40-year-long teaching career at Howard University and West Virginia State College. The National Association of Mathematicians Cox-Talbot Address is delivered annually at the Joint Mathematics Meetings in his honor, and the Elbert F. Cox Scholarship Fund at Howard University is used to help Black students achieve higher educational goals.

\section{WALTER \\ RICHARD TALBOT (1907-1977) U. of Pittsburgh BS 1931, MA 1933, PhD 1934}

Walter Richard Talbot accepted an assistant professorship in mathematics in 1934 at Lincoln University in Missouri, moving through the ranks to full professor while also serving as department chair (1940-1963), dean of men (1939-1944), registrar (1946-48), and acting dean of instruction (1955-

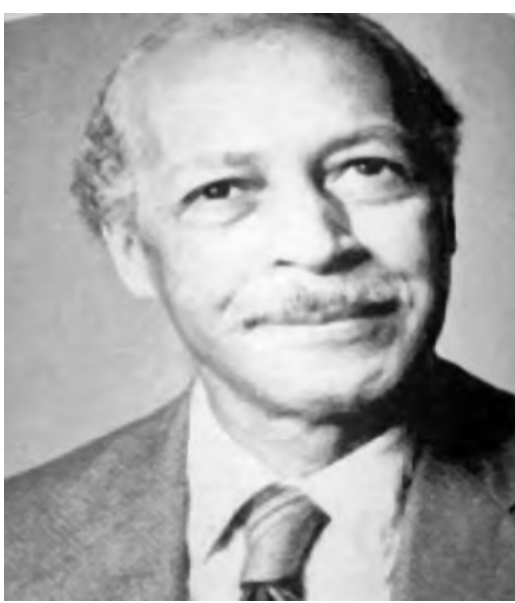

Walter Richard Talbot: fourth African American to receive a PhD in math, a founder of the National Association of Mathematicians.
1957). In 1963 Talbot accepted the positions of professor and department chair of mathematics at Morgan State University, remaining there until he retired in 1977. Talbot 
served the MAA in several significant capacities, and he was a major driving force among the seventeen who came together in January 1969 to found the National Association of Mathematicians (NAM). More than any other single individual, it was Talbot's leadership, guidance, organizational skills, and networking skills that raised funds for the establishment of NAM. In 1978, at a luncheon "In Memorial," Morgan State University named a scholarship in his honor. In 1980, NAM honored Talbot with the inauguration of the annual Cox-Talbot Address.

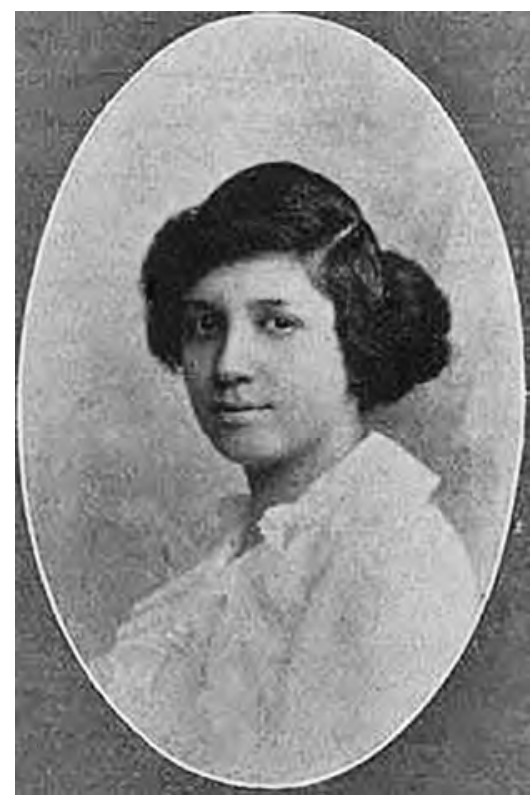

Euphemia L. Haynes: The first African American woman to earn a PhD in mathematics.

EUPHEMIA L. HAYNES ${ }^{2}$ (18901980) Smith C. BA 1914, U. Chicago MA 1930, Catholic U. PhD 1943

Martha Euphemia Loften Haynes was the first Black American woman to earn a $\mathrm{PhD}$ in mathematics. Haynes spent all of her professional life in Washington, DC. She was the first woman to chair the DC School Board. Haynes also served as math chair at Dunbar High School and at DC's Teachers College. At Miner Teachers College she established the math department, and at Howard University she taught part-time as an adjunct professor. She was a prominent figure in bringing about integration in the DC public school system and in the Archdiocesan Council of Catholic Women. Haynes received many awards, including election as Fellow in the American Association for the Advancement of Science in 1962. NAM honored her and two other Black women mathematicians by establishing the Haynes-Granville-Brown Colloquium Lecture Series that is given annually at NAM's national meeting at the JMM. Her highest awards resulted from her humanitarianism and generosity. Upon her death, US\$700,000 was bequeathed to Catholic University in a trust for a chair and student loan fund in her name.

\section{DUDLEY WELDON WOODARD (1881-1965) Wilberforce U AB 1903, U. Chicago BS 1906, MS 1906, U. Penn PhD 1928}

Dudley Weldon Woodard managed to get his master's thesis and other research papers published in repu-

\footnotetext{
${ }^{2}$ See the article on Haynes in the October 2017 Notices www . ams. org/publications/journals/notices/201709/rnoti-p995. pdf.
}

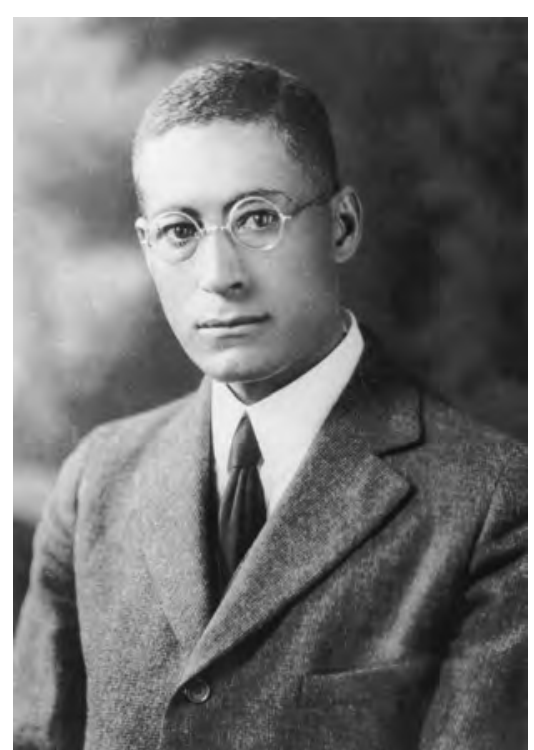

Dudley Weldon Woodard: The second African American to earn a PhD in mathematics, established the mathematics MS degree program at Howard University in 1929. cluding recruiting Elbert Cox. Woodard devoted his entire professional life to the promotion of excellence in mathematics through the advancement of his students, in teaching, and in research. Woodard's students who also earned the $\mathrm{PhD}$ degree in mathematics included $\mathrm{W}$. W. S. Claytor, George Butcher, Majorie Lee Brown, and Eleanor Jones. NAM honored Woodard with the naming of the Claytor-Woodard Lecture, given annually at NAM's national meeting at the Joint Mathematics Meetings.

\section{WILLIAM W. \\ CLAYTOR (1908- \\ 1967) Howard U. \\ BS 1929, MS 1930, \\ U. Penn. PhD 1933}

William Waldron Schieffelin Claytor was Dudley Woodard's most promising student at Howard. Thus it was not surprising that William Claytor was recommended for further studies at the University of Pennsylvania. Claytor quickly earned himself an outstanding reputation at U. Penn., where he won the Harrison Fellowship in Mathematics-the

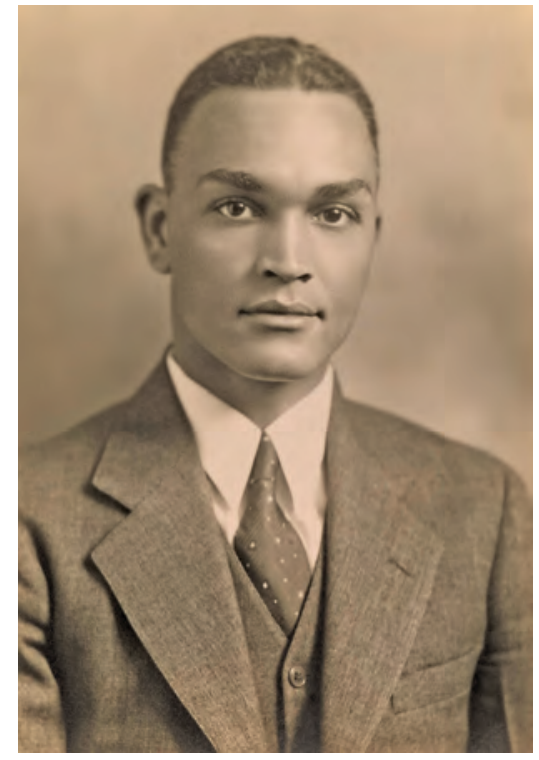

William W. Claytor: The third African American to earn a $\mathrm{PhD}$ in mathematics and a distinguished topologist. 
most prestigious award U. Penn offers. His dissertation under J. R. Kline was also well received by the faculty. After the completion of his PhD, Claytor accepted a teaching position at West Virginia State College, where he remained for three years. In 1937 he was awarded a Rosenwald Fellowship and pursued postdoctoral studies at the University of Michigan, where R. L. Wilder had attracted an able and experienced group of topologists. Kline had written Wilder about Claytor's abilities, and they both were pleased that Claytor was able to join the group at Michigan, which included S. Eilenberg, W. L. Ayers, E. W. Miller, and S. B. Myers. Claytor's published mathematical work, on imbeddability and Peano continua, attracted considerable attention throughout the topological community and still does today. At the end of his postdoctoral studies at Michigan, Claytor was recommended by his colleagues in topology for a faculty position at Michigan. The administration took a firm stand that no such appointment would be made, as did other major research institutions. After this experience Claytor apparently lost interest in doing research at a major university. In 1947 Blackwell invited Claytor to Howard, where he served well until he retired in 1965. In 1980 NAM named the Claytor-Woodard Lecture in his honor.

\section{DAVID BLACKWELL (1919-2010) U. IIIinois AB 1938, MA 1939, PhD 1941}

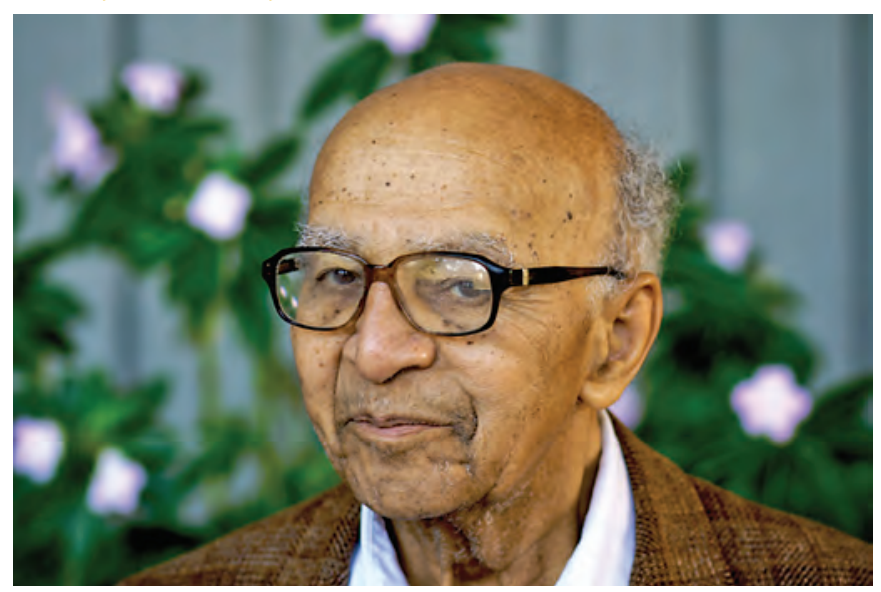

David Blackwell: first Black professor at UC Berkeley, first Black American inducted into the National Academy of Sciences (1965).

David Harold Blackwell took an elementary analysis course as a junior in college and fell in love with mathematics. After earning his $\mathrm{PhD}$ in 1941, he held a one-year postdoctoral fellowship at the Institute for Advanced Study in Princeton. Colleagues in Princeton wished to extend Blackwell's appointment at the Institute; however, the president of Princeton organized a great protest. Blackwell then knew that a white university would not hire him. He applied to all 105 Black Colleges in the country. Blackwell joined the faculty at Howard in 1944 as an instructor. By 1947, he was professor and department chair. Blackwell searched for mathematics around Washington and met $\mathrm{M}$.
A. Girschick of the Department of Agriculture, and they became collaborators in many works. Their 1954 book, Theory of Games and Statistical Decisions, is now a classic. By 1954 Blackwell had published more than twenty papers. He had spent a couple of summers at the RAND Corporation and was visiting professor of statistics at Stanford University from 1950 to 1951. In 1954 he gave an invited address in probability at the International Congress of Mathematicians in Amsterdam. Immediately afterward he was appointed professor of statistics at UC Berkeley. He served for many years as chair of the statistics department before retiring. He produced numerous publications at UC Berkeley and he received many honors and recognitions, including a number of honorary doctorate degrees. He was elected as the first African American to the National Academy of Sciences. David Blackwell is considered to be a world-class African American mathematician, mechanical engineer, and nuclear scientist. NAM named the summer Blackwell Lecture at the MAA MathFest in his honor. In 2002 the Mathematical Sciences Research Institute in Berkeley and Cornell University established the BlackwellTapia Award in honor of Blackwell and Richard A. Tapia, two distinguished mathematical scientists who have been inspirations to more than a generation of African American and Hispanic American students and professionals.

\section{J. ERNEST WILKINS (1923-2011) U. Chicago BS 1940, MS 1941, PhD 1942}

Jesse Ernest Wilkins, initially frequently referred to by the media as the "Negro genius," was a world-class American scientist-mathematician, mechanical engineer, and nuclear scientist. After earning three degrees in mathematics at U. Chicago, Wilkins earned degrees in mechanical engineering from NYU. Wilkins worked as a contributor to the Manhattan Project during World War II, served several important scientific posts with distinction over a half century, and aided in the recruitment of minority students to take mathematics and science courses. Wilkins wrote almost 100 scientific papers (over 55 in mathematics), earning many awards and much recognition. He was the second African American elected to the National Academy of Engineering (1965). He later served as a faculty member at Howard, assisting the mathematics department in establishing in 1975 the first PhD program in mathematics

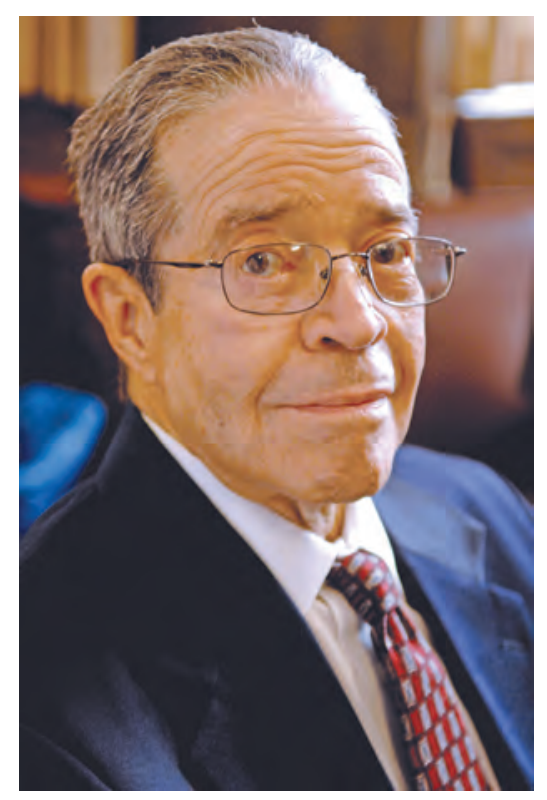

J. Ernest Wilkins Jr.: earned PhD in mathematics at age nineteen. 
at a Historically Black College or University (HBCU). Coming out of one of his many retirements, Wilkins became Distinguished Professor of Mathematics and Physics at Clark Atlanta University in the late 1990s. In his honor, NAM established a J. Ernest Wilkins Lecture, which is given annually at NAM's fall Undergraduate MATHFest.

\section{ALBERTTURNER BHARUCHA-REID (1927-1985) lowa St. BS 1949}

Albert Turner Bharucha-Reid was an African American research mathematician and probability theorist who worked extensively on probability theory, Markov chains, and statistics. He produced more than 70 papers and six books; his work touched on such diverse fields as economics, physics, and biology. Bharucha-Reid was born Albert Turner Reid in Hampton, Virginia. He studied math and biology at Iowa State

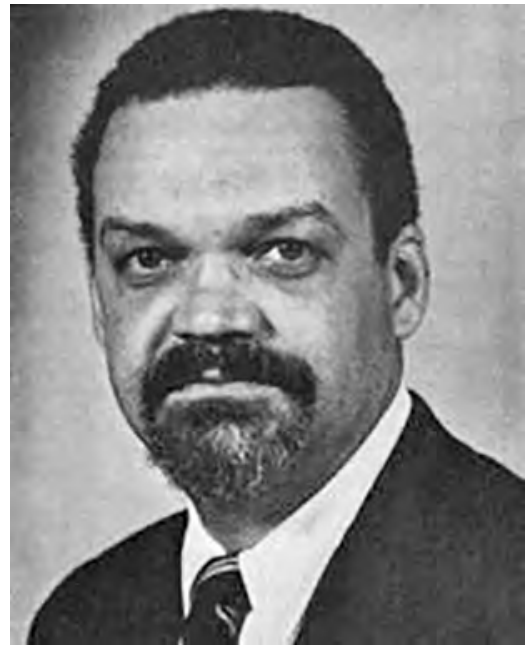
Albert Turner Bharucha-Reid: a world-class African American mathematician who never earned a PhD degree, a great probability theorist who wrote over 70 papers and six books and supervised thirteen PhD students.
NAM named a lectureship in his honor; it is given annually at NAM's Spring Faculty Research-Teaching Conference.

In closing, I invite you to also read about five great African American mathematics teachers:

1. Clarence F. Stephens

2. Marjorie Lee Browne

3. Claude B. Dansby

4. Abdulalim A. Shabazz

5. Etta Z. Falconer

\section{Image Credits}

Woodcut image of Benjamin Banneker is in the public domain. Photo of Edward Alexander is in the public domain. Photo of Elbert Frank Cox is in the public domain.

Photo of Walter Richard Talbot courtesy of Johnny L. Houston.

Photo of Euphemia L. Haynes is in the public domain.

Photo of Dudley Weldon Woodard courtesy of the Moorland-Spingarn Research Center, Howard University Archives.

Photo of William W. Claytor courtesy of Raymond Louis Wilder Papers, Archives of American Mathematics, e_math_02076, Dolph Briscoe Center for American History, University of Texas at Austin.

Photo of David Blackwell courtesy of UC Berkeley.

Photo of J. Ernest Wilkins Jr. by Dan Dry used under terms of the Creative Commons Attribution-Share Alike 3.0 Unported license.

Photo of Albert Turner Bharucha-Reid courtesy of Ronald E. Mickens, Executor of the intellectual properties of the late Prof. Albert Turner Bharucha-Reid.

\section{ABOUT THE AUTHOR}

Johnny L. Houston is cofounder of NAM, author of The History of NAM (2000) and the upcoming American Mathematicians of Diverse Ethnicities (2019), and a NAM Lifetime Achievement Awardee (1999).

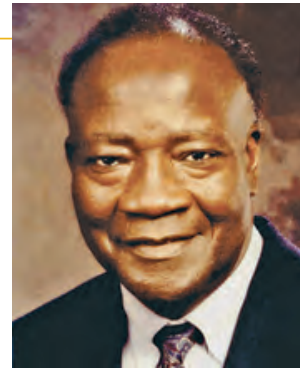

Johnny L. Houston

Phiroze Bharucha, and he legally changed his name to Albert Turner Bharucha-Reid. He taught and lectured in the United States, Europe, and India, holding professorships or research positions at Columbia, UC Berkeley, Oregon, Georgia Tech, Wayne St., the Polish Academy of Science, and Atlanta University (now Clark Atlanta University). In 1970 he was appointed dean of the School of Arts and Sciences at Wayne St., where he graduated his thirteen PhD students. Bharucha-Reid was the editor of about ten international scholarly journals. He bequeathed all of his scientific materials to the Amistad Research Center at Tulane. In May 1984, he was awarded an honorary doctorate of science by Syracuse University. The Citation at Syracuse Commencement stated "We honor you as a founder of Probabilistic Analysis. A mathematician of great distinction, you sensed the importance and glimpsed the possibilities of new developments in your field and then led the way to the applications of new knowledge." This Citation was rather descriptive of much of his life work as a scholar. 